\title{
First report on dung beetles in intra-Amazonian savannahs in Roraima, Brazil
}

\author{
Filipe M. França ${ }^{1,2,5}$, Vanesca Korasaki ${ }^{3}$,Julio Louzada ${ }^{1,2}$, Fernando Z. Vaz-de-Mello ${ }^{4}$ \\ ${ }^{1}$ Universidade Federal de Lavras, Departamento de Biologia, Setor de Ecologia, Laboratório de Ecologia e \\ Conservação, Lavras, MG, Brazil. \\ ${ }^{2}$ Lancaster University, Lancaster Environment Center, Lancaster, Lancashire, UK. \\ ${ }^{3}$ Universidade do Estado de Minas Gerais, Departamento de Ciências Exatas e da Terra, \\ Frutal, MG, Brazil. \\ ${ }^{4}$ Universidade Federal do Mato Grosso, Departamento de Biologia e Zoologia, Instituto de Biociências, \\ Cuiabá, MT, Brazil. \\ ${ }^{5}$ Corresponding author: Filipe Machado França, e-mail: filipeufla@gmail.com
}

\begin{abstract}
FRANÇA, F.M., KORASAKI, V., LOUZADA, J., VAZ-DE-MELLO, F.Z. First report on dung beetles in intra-Amazonian savannahs in Roraima, Brazil. Biota Neotropica. 16(1): e0034. http://dx.doi.org/ 10.1590/1676-0611-BN-2015-0034
\end{abstract}

\begin{abstract}
This is the first study to address the dung beetle (Coleoptera: Scarabaeidae: Scarabaeinae) diversity in intra-Amazonian savannahs in the state of Roraima, Brazil. Our aim was to survey the dung beetle fauna associated with these savannahs (regionally called 'lavrado'), since little is known about the dung beetles from this environment. We conducted three field samples using pitfall traps baited with human dung in savannah areas near the city of Boa Vista during the rainy seasons of 1996, 1997, and 2008. We collected 383 individuals from ten species, wherein six have no previous record in intra-Amazonian savannahs. The most abundant species were Ontherus appendiculatus (Mannerheim, 1829), Canthidium aff. humerale (Germar, 1813), Dichotomius nisus (Olivier, 1789), and Pseudocanthon aff. xanthurus (Blanchard, 1846). We believe that knowing the dung beetles diversity associated with the intra-Amazonian savannahs is ideal for understanding the occurrence and distribution of these organisms in a highly threatened environment, it thus being the first step towards conservation strategy development.
\end{abstract}

Keywords: Tropical environments, new species occurrence, 'lavrado', Scarabaeinae.

FRANÇA, F.M., KORASAKI, V., LOUZADA, J., VAZ-DE-MELLO, F.Z. Primeiro registro de besouros rola-bosta em savanas intra-amazônicas de Roraima, Brasil. Biota Neotropica. 16(1): e0034. http://dx.doi.org/10.1590/1676-0611-BN-2015-0034

Resumo: Este é o primeiro estudo da diversidade de besouros rola-bosta (Coleoptera: Scarabaeidae: Scarabaeinae) nas savanas intra-amazônicas de Roraima, Brasil. Nosso objetivo foi inventariar a fauna de besouros associada com savanas (conhecidas regionalmente como 'lavrado'), uma vez que pouco se sabe sobre esses besouros nesse ambiente. Nós amostramos em savanas próximas a cidade de Boa Vista durante a estação chuvosa nos anos 1996, 1997 e 2008, utilizando armadilhas pitfall iscadas com fezes humanas. Coletamos 383 indivíduos de dez espécies, das quais seis não haviam ocorrência prévia para savanas intraamazônicas. As espécies mais abundantes foram Ontherus appendiculatus (Mannerheim, 1829), Canthidium aff. humerale (Germar, 1813), Dichotomius nisus (Olivier, 1789) e Pseudocanthon aff. xanthurus (Blanchard, 1846). Nós acreditamos que conhecendo a diversidade de besouros associada às savanas intra-Amazônicas se torna ideal para o entendimento da ocorrência e distribuição desses organismos em um ambiente altamente ameaçado, sendo o primeiro passo para a tomada de estratégias de conservação.

Palavras-chave: Ambientes tropicais, nova ocorrência de espécies, lavrado, Scarabaeinae.

\section{Introduction}

The Amazon environment comprises a mosaic of ecosystems, including deciduous forests, 'campinaramas' (meadows), semideciduous seasonal forests, rain and montane forests, dry land forests, floodplain forests, woodlands and intra-Amazonian savannahs (Junk 1983, Ribeiro et al. 1999). The Brazilian intraAmazonian savannah landscape encompasses a predominantly grassy-woody vegetation (e.g. grasses, sedges, and small herbs), with low arboreal-shrub density (Barbosa et al. 2007, Sarmiento
1984) and specific edaphic characteristics (Cavalcante et al. 2014, Sanaiotti et al. 2002). These savannahs are located in the extreme north of the Brazilian Amazon forest, mainly in the triple border between Venezuela, Brazil and Guyana (Barbosa et al. 2007, Barbosa \& Fearnside 2005, Prance 1996). This eco-region known as Guyana's shield (Hubber 2006) comprises the largest contiguous area of intra-Amazonian savannah (around $54.000 \mathrm{~km}^{2}$ ), of which approximately $72 \%$ are located in the northeastern region of the Roraima State in Brazil (Barbosa \& Fearnside 2005, Barbosa \& Campos 2011, Copobianco et al. 2001, Ferreira 2001). 
Furthermore, those savannahs are regionally known as 'lavrado' (Barbosa et al. 2007, Sanaiotti 1997), which means 'place where the trees are absent' (Vanzolini \& Carvalho 1991) and reflects its typical non-forest vegetation.

Despite a review about the Phanaeini tribe (Pacheco \& Vaz-deMello 2015), no work to our knowledge has reported the dung beetle fauna from the intra-Amazonian savannahs in Roraima. The dung beetles are a responsive taxonomic group (Bicknell et al. 2014), with more than 600 species recorded in Brazil (Vaz-de-Mello 2000) and distributed throughout all Brazilian terrestrial ecosystems. Regarding their diversity within Brazilian opened areas, studies have recorded between 13 and 66 species from the Brazilian southeastern savannahs (known as 'cerrado') and pasturelands (Abot et al. 2012, Almeida et al. 2011, Durães et al. 2005, Gries et al. 2012, Milhomem et al. 2003, Silva \& Audino 2011, Silva et al. 2010, Vieira \& Silva 2012). Furthermore, 15 dung beetle species were reported from the intra-Amazonian savannahs near to Alter do Chão village, state of Pará, Brazil (Louzada et al. 2010, Matavelli \& Louzada 2008). Hence, considering the dung beetles' ecological importance in many ecosystem processes (Nichols et al. 2008) and the poor knowledge about their fauna from the largest intra-Amazonian savannah area in Brazil, here we aimed to present the dung beetle species that were sampled within three lavrado savannahs of Roraima state, Brazil.

\section{Materials and Methods}

The city of Boa Vista in the state of Roraima has a humid tropical climate, characterized as a rainy summer, which extends from April to September, and a dry season from October to March. The average annual rainfall and temperature are respectively $1612 \pm 400 \mathrm{~mm}$ and $27.4{ }^{\circ} \mathrm{C}$ (Barbosa \& Fearnside 2005, Meneses et al. 2007). We used dung-baited pitfall traps to sample dung beetles during September 1996, July 1997, and November 2008 in three savannah areas near Boa Vista, Roraima, Brazil.

The first sampling period (1996) was carried out in a small savannah area in the municipality of Cantá $\left(2^{\circ} 46^{\prime} \mathrm{N} 60^{\circ} 38^{\prime} \mathrm{W}\right)$ located on the margin of the 'Rio Branco' river. The region is a large lavrado area continuous with small anthropogenic areas and subjected to floods during the rainy season. We installed five pitfall traps in this area, separated at least $50 \mathrm{~m}$ apart from each other, baited with human dung and exposed for $48 \mathrm{~h}$ to the dung beetle community. In the second sampling period (1997), a large area of lavrado in the 'Serra da Moça' region (north of Boa Vista, approx. $\left.6^{\circ} 12^{\prime} \mathrm{N} 60^{\circ} 41^{\prime} \mathrm{W}\right)$ was sampled. We placed seven pitfall traps, located at least $50 \mathrm{~m}$ apart, baited with human dung and collected daily during five days with two exchanges of bait during the sampling period. In the third sampling period (2008), we sampled a large area of lavrado located on the opposite side of the Rio Branco river $\left(02^{\circ} 62^{\prime} \mathrm{N} 60^{\circ} 72^{\prime} \mathrm{W}\right)$. We used seven pitfall traps, separated at least $50 \mathrm{~m}$ apart from each other, baited with human dung and left in the field for $48 \mathrm{~h}$.

Pitfall traps were plastic containers $(14 \mathrm{~cm}$ in diameter; $9 \mathrm{~cm}$ deep) buried in the ground with the opening at ground level, and with approximately $30 \mathrm{~g}$ of bait. We covered each pitfall with a lid to protect it from the rain and filled each one with $250 \mathrm{ml}$ of a saline solution and detergent. After the exposition in the field, we collected, sorted, mounted and identified all dung beetles to the lowest possible taxonomic level. All voucher specimens were deposited in the Reference Collection of Neotropical Scarabaeinae in the Insect Ecology and Conservation Laboratory, Universidade Federal de Lavras and in the Entomology section of the Zoological Collection at Universidade Federal de Mato Grosso, Brazil. To further discussions about the geographical distribution and feeding habits of each genera and species here collected, we reviewed published and unpublished bibliographical references about the species ecology and distribution. Furthermore, we present an illustrated guide from each identified species we have found.

\section{Results and Discussion}

We collected 383 dung beetles belonging to ten species and eight genera (Table 1). From the collected species, only Canthidium sp. could not be identified and it is a possible new species. Ontherus appendiculatus, Canthidium aff. humerale, Dichotomius nisus, and Pseudocanthon aff. xanthurus were the most abundant species. As such, we have sampled six species without any previous occurrence from intra-Amazonian savannahs, as only the dung beetle species $O$. appendiculatus, $D$. nisus, $P$. aff. xanthurus and $C$. mutabilis have been previously recorded in these environments (Génier 1996, Louzada et al. 2010, Matavelli \& Louzada 2008).

Most species we found belong to species-clusters that have been collected within dry, open and highly disturbed environments on the American continent, some of them with records from Argentina (Damborsky et al. 2015), Mexico (Novelo et al. 2007), Ecuador (Carpio et al. 2009), Venezuela (Lozano 2010), Colombia (Noriega et al. 2007) and Costa Rica (Padilla-Gil \&

Table 1. Dung beetle species collected in three intra-Amazonian savannahs close to Boa Vista, Roraima, Brazil. In each sampling period, we sampled a different area.

\begin{tabular}{|c|c|c|c|c|}
\hline \multirow[b]{2}{*}{ Species } & \multicolumn{3}{|c|}{ Sampling period } & \multirow{2}{*}{$\begin{array}{c}\text { Total } \\
\text { individuals }\end{array}$} \\
\hline & 1996 & 1997 & 2008 & \\
\hline Canthidium aff. humerale (Germar, 1813) & 1 & 10 & 50 & 61 \\
\hline Canthidium sp. & 5 & 0 & 0 & 5 \\
\hline Canthon (Canthon) aff. scrutator Balthasar, 1939 & 0 & 2 & 0 & 2 \\
\hline Canthon (Canthon) aff. mutabilis Lucas, 1959 & 0 & 5 & 0 & 5 \\
\hline Malagoniella astyanax (Oliver, 1789) & 0 & 0 & 1 & 1 \\
\hline Pseudocanthon aff. xanthurus (Blanchard, 1846) & 4 & 21 & 22 & 47 \\
\hline Dichotomius nisus (Olivier, 1789) & 13 & 22 & 14 & 49 \\
\hline Ontherus appendiculatus (Mannerheim, 1829) & 161 & 0 & 3 & 164 \\
\hline Onthophagus aff. hirculus Mannerheim, 1829 & 10 & 0 & 0 & 10 \\
\hline Coprophanaeus gamezi Arnaud, 2002 & 0 & 39 & 0 & 39 \\
\hline
\end{tabular}


Halffter 2007). In Brazil, those have been registered within the semi-arid scrub forest (known as 'caatinga') (Hernandéz 2007, Lopes et al. 2006, Silva et al. 2007), coastal sandy vegetation ('restinga') (Costa et al. 2014), coastal low land forests ('Tabuleiro' forests) (Endres et al. 2007) and native and exotic pasturelands (Almeida et al. 2011, Costa et al. 2009, 2013, Silva et al. 2010, Silva et al. 2011, 2014). In addition, the species reported here were also found within highly impacted Brazilian forests, such as northeastern fragments of Atlantic forest (Salomão \& Iannuzzi 2015, Viegas et al. 2014), planted Eucalyptus sp. forests (Audino et al. 2011) and Amazonian secondary forests, savannahs and agricultural areas (Korasaki et al. 2012, Louzada et al. 2010, Matavelli \& Louzada 2008).

The number of dung beetle species and individuals reported here was lower than in other intra-Amazonian savannahs (Louzada et al. 2010, Matavelli \& Louzada 2008), southern cerrado (Abot et al. 2012, Almeida et al. 2011, Durães et al. 2005, Gries et al. 2012, Silva et al. 2010, Vieira \& Silva 2012) and native grasslands of the 'Pampa' region (Silva et al. 2011). We believe this lower species-rich sample can be due the historical isolation of the intra-Amazonian from the cerrado savannahs in central Brazil during the Pleistocene period (Sanaiotti et al. 2002), besides some natural specific habitat characteristics, such as edaphic factors, vegetation structure and fire occurrence (Barbosa \& Fearnside 2005, Louzada et al. 2010). Henceforward, we will discuss the knowledge concerning the distribution and ecology of each identified species.

Canthidium Erichson (1847): Considered as one of the most diverse dung beetle groups (Halffter \& Martínez 1966), this genus needs urgent revision, which may result in the creation of new genera. It currently includes about 170 described species, mainly recorded with dung-baited pitfalls in Neotropical forests and savannahs (Gill 1991, Silva et al. 2014, Vaz-de-Mello \& Louzada 1997, Vaz-de-Mello et al. 1998). There are also some records of species sampled with carrion-baited pitfalls or consuming rooting fruit, fungi and dead insects (Medri \& Lopes 2001, Silva \& Audino 2011, Silva et al. 2014). Hence, species have been suggested as myrmecophilous associated with nests of Atta ants Fabricius, 1804, probably exploiting rotting fungi (Falqueto et al. 2005). Canthidium aff. humerale (Figure 1A) belongs to a species-cluster that contains species considered as coprophagous (Silva et al. 2007) and distributed within many opened environments. Species in this cluster have been recorded in northeastern Brazilian grassland areas (Almeida et al. 2011, Costa et al. 2009, Silva et al. 2007), Tabuleiro forests (Endres et al. 2007), secondary regeneration zones between caatinga and cerrado (Lopes et al. 2006) and transitional regions between the Amazon forest and cerrado (Andrade et al. 2011). The other Canthidium species we found could not be identified accurately, thus no further comments are possible about its ecology and distribution.

Canthon Hoffmannsegg (1817): Featuring approximately 200 species, this genus has been studied at a supraspecific level, except for some species that are not yet grouped into any subgenera. It is an American group, with species mainly found from Argentina to Canada (Vaz-de-Mello 2000). Although most species are considered as copro-necrophagous, other feeding habits, including fungi and debris feeders (Vaz-de-Mello 1999b) and ant predation (Hertel \& Colli 1998, Vaz-de-Mello et al. 1998,
Villalobos et al. 1998) were also recorded. The subgenus Canthon (Canthon) Hoffmannsegg, 1817 includes mainly coprophagous or necrophagous dung beetles, despite species preying on ants (Cantil et al. 2014, Forti et al. 2012, Villalobos et al. 1998) and feeding on dead insects and millipedes (Villalobos et al. 1998). Canthon (Canthon) aff. scrutator Balthasar, 1939 (Figure 1B) belongs to the Canthon virens species-group (Halffter \& Martínez 1977), which is distributed throughout the northern Amazon Basin, Guyana and Atlantic Forest region. This species-group comprises copro-necrophagous dung beetles, also recorded consuming insect carcasses (Forti et al. 2012) or sampled with carrion-baited pitfall traps (Salomão \& Iannuzzi 2015). We believe the species Canthon (Canthon) aff. mutabilis Lucas, 1859 (Figure 1C) needs urgent revision, given that individuals identified as $C$. mutabilis may comprise a complex group of different species. This species-group have been recorded within open environments in America, such as Colombia (Noriega et al. 2007), Costa Rica (Padilla-Gil \& Halffter 2007), Argentina (Boito et al, 2009) and primary forests from Suriname (Larsen 2011). In Brazil, there are samples from flight intercept traps (Audino et al. 2011, Costa et al. 2009) and pitfalls baited with dung and carrion (Costa et al. 2013, 2014, Silva et al. 2007, 2014, Silva \& Audino 2011).

Malagoniella Martínez, 1961: Halffter \& Martínez (1966) reviewed this genus, which includes nine colorful metallic dung beetle species distributed across the Neotropical region, from USA (Texas) to Argentina (Padilla-Gil \& Halffter 2007). Malagoniella astyanax (Oliver 1789) (Figure 1D) belongs to a species complex that is currently being revised. It has been found in the Brazilian caatinga (Hernandéz, 2007, Silva et al. 2007, Vieira \& Silva 2012), Ecuadorian Amazon (Carpio et al. 2009), Colombia (Escobar 1997), Costa Rica (Padilla-Gil \& Halffter 2007), Mexico (Novelo et al. 2007), Venezuela (FerrerParis et al. 2013), Bolivia (Vidaurre et al. 2008) and Guyana (F.Z. Vaz-de-Mello, unpublished data). Species in this group have been considered as nocturnal (Hernandéz 2007), sampled by pitfall traps baited with dung and carrion (Carpio et al. 2009, Hernandéz 2007, Novelo et al. 2007, Silva et al. 2007).

Pseudocanthon Bates, 1887: This genus is small, including nine species distributed from the USA to Argentina and Antilles (Halffter \& Matthews 1966, Padilla-Gil \& Halffter 2007). Although small, it urgently needs taxonomic revision, at least for the continental species. The species Pseudocanthon aff. xanthurus (Figure 1E) is a complex of species, which is difficult to identify (Korasaki et al. 2012) and, as the genus, it needs taxonomic revision. Although extensively sampled with dung baited pitfalls, the species have been considered as generalist (Andrade et al. 2011), with records from open habitats in Colombia and Venezuela (Ferrer-Paris et al. 2013). In Brazil they have been reported within pastures and grasslands (Costa et al. 2009, Schiffler et al. 2015, Silva et al. 2014), caatinga (Lopes et al. 2006), degraded restinga (Costa et al. 2014), northeastern Atlantic forest (Costa et al. 2013, Salomão \& Iannuzzi 2015), intra-Amazonian savannahs (Matavelli \& Louzada 2008) and Amazonian agricultural areas (Korasaki et al. 2012).

Dichotomius Hope (1838): According to the last taxonomic revision, this genus features approximately 165 valid species widely distributed from the USA to Argentina (Luederwaldt 1929), 

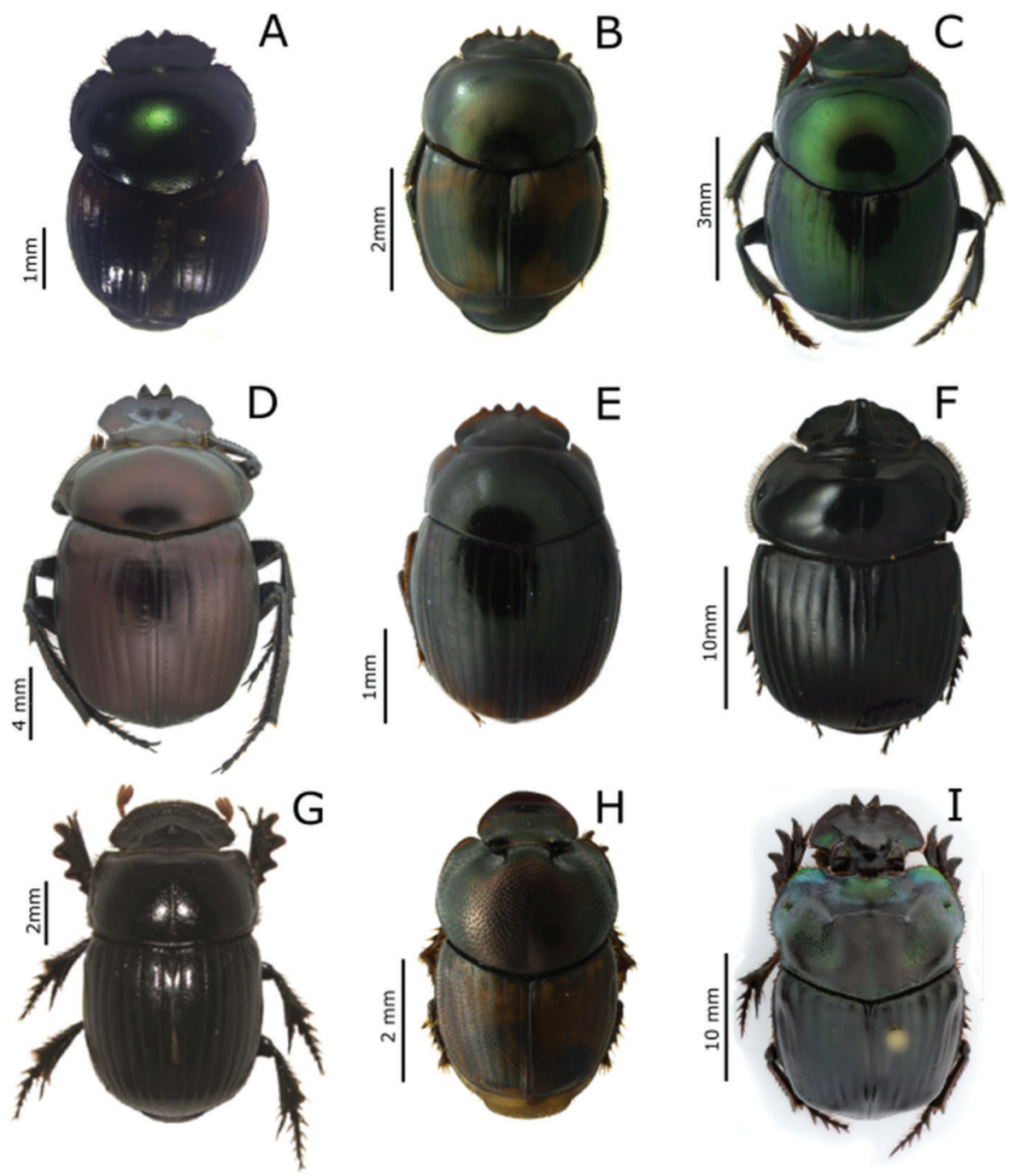

Figure 1. Dung beetle species sampled from intra-Amazonian savannahs in the state of Roraima: (A) Canthidium aff. humerale; (B) Canthon aff. scrutator; (C) Canthon aff. mutabilis; (D) Malagoniella astyanax (extracted from Vieira \& Silva, 2012); (E) Pseudocanthon aff. xanthurus; (F) Dichotomius nisus; (G) Ontherus appendiculatus (extracted from Vidaurre et al., 2008); (H) Onthophagus aff. hirculus; (I) Coprophanaeus gamezi (extracted from Pacheco \& Vaz-de-Mello, 2015).

especially in Neotropical forest and savannah areas (Vaz-de-Mello 1999b, 2000). Although most species are coprophagous, we believe there are some exceptions. Dichotomius nisus (Olivier 1789) (Figure $1 \mathrm{~F})$ is considered a nocturnal coprophagous-generalist species (Hernandéz 2007, Silva et al. 2007, Vieira et al. 2008), commonly occurring within opened and/or disturbed environments (Filgueiras et al. 2015, Nunes et al. 2012). It is widely distributed, with records from Guyana (Boilly \& Vaz-de-Mello 2014), Argentinian Chaco (Damborsky et al. 2015), transitional forests in Bolivia (Vidaurre et al. 2008), Colombia Andes (Putumayo region) (Escobar et al. 2005) and Venezuelan dry forests and pastures (Ferrer-Paris et al. 2013, Lozano 2010). In Brazil, it has been sampled with both dung and carrion-baited pitfall traps within more than 17 states (Louzada et al. 2007). Accordingly, it has been extensively collected from the northern intra-Amazonian savannahs (Koller et al. 1999, Matavelli \& Louzada 2008) to southern Campanha region (Silva et al. 2008), within non-native forests of Eucalyptus sp. (Audino et al. 2011). Furthermore, there are records from restinga (Costa et al. 2014, Schiffler et al. 2015, Vieira et al. 2008), Tabuleiro forest (Endres et al. 2007), caatinga (Hernandéz 2007,
Medina \& Lopes 2014, Santos et al. 2014, Vieira \& Silva 2012), Atlantic forest fragments (Costa et al. 2013, Flechtmann et al. 2009, Salomão \& Iannuzzi 2015, Silva et al. 2015, Viegas et al. 2014), cerrado (Almeida et al. 2011, Rodrigues et al. 2010) and many pasturelands and altered grasslands (Costa et al. 2009, Filgueiras et al. 2015, Louzada \& Silva 2009, Louzada et al. 2007, Puker et al. 2013, Scheffler 2005, Silva et al. 2011).

Ontherus Erichson, 1847: This genus is distributed from Mexico to Argentina and was recently reviewed by Génier (1996), which resulted in 56 species divided into three subgenera. We believe that most of the species are coprophagous; however, there are some species associated with sediment deposits within ant colonies of Atta Fabricius, 1804 and Acromyrmex Mayr, 1865 (Halffter \& Halffter 2009). Ontherus appendiculatus (Mannerhein, 1829) (Figure 1G), although considered as typically coprophagous, has been collected also with carrion (Flechtmann et al. 2009, Rosa et al. 2011, Silva et al. 2007). Widely distributed in South America (Génier 1996), O. appendiculatus has been reported in Argentina, Bolivia, Brazil, Colombia, Ecuador, French Guyana, 
Guyana, Paraguay, Uruguay and Venezuela (Génier 1996, Louzada et al. 2007, Vidaurre et al. 2008, Ferrer-Paris et al. 2013). In Brazil, it has a broad distribution, with records from intra-Amazonian savannahs (Matavelli \& Louzada 2008), Tabuleiro forest (Lima et al. 2013) and Atlantic forest fragments (Silva et al. 2015). Furthermore, it has been recorded in transitional forests between cerrado and Amazon forest (Andrade et al. 2011), and cerrado within Pantanal regions (Louzada et al. 2007, Puker et al. 2013, Rodrigues et al. 2010).

Onthophagus Latreille, 1802: It is a very diverse and cosmopolitan genus with more than 2000 species (Tarasov \& Kabakov 2010). Although considered as coprophagous, there are species attracted by the defense secretions from millipedes (Brühl \& Krell 2003, Schmitt et al. 2004) or associated with caves (Slay et al. 2012), bird nests (Kristofík et al. 2003) and rodents (Sánchez-Huerta et al. 2015). Onthophagus aff. hirculus Mannerheim, 1829 (Figure 1H) belongs to a complex of species that is taxonomically close to $O$. hirculus and needs urgent taxonomic revision. Those species have been considered as coprophagous and generalist (Hernandéz 2007, Silva et al. 2011), collected by pitfall traps baited with different types of dung, rotting fruits and carcass (Audino et al. 2011, Flechtmann et al. 2009, Puker et al. 2013, Rosa et al. 2011, Silva \& Audino 2011, Silva et al. 2008). This species-complex have been recorded in South American open areas at altitudes $<1000 \mathrm{~m}$, such as Argentinian Chaco (Damborsky et al. 2015), Colombian secondary dry forests (Noriega et al. 2007) and Bolivian transitional forests (Vidaurre et al. 2008). In Brazil, they have been collected within pasturelands (Puker et al. 2013, Silva et al. 2010, Silva et al. 2014), caatinga (Hernandéz 2007, Santos et al. 2014, Silva et al. 2007, Vieira \& Silva 2012) and restinga areas (Costa et al. 2014, Vieira et al. 2008). In addition, they have been recorded in Atlantic forest fragments (Silva et al. 2015) and transitional areas between the Amazon forest and cerrado (Andrade et al. 2011).

Coprophanaeus d'Olsoufieff, 1924: Reviewed by Edmonds \& Zidek (2010), this genus includes 38 species distributed among three subgenera and eight species recorded from Texas to Argentina. Coprophanaeus gamezi Arnaud, 2002 (Figure 1I) has been found in tropical dry forests in Colombia (Solís et al. 2011), the coast and provinces in Venezuela (Ferrer-Paris et al. 2013, Lozano 2010) and adjacent Amazon regions of Brazil, Colombia and Guyana (Edmonds \& Zidek 2010). Accordingly, it has been suggested as preferring open habitats and readily invading pasturelands (Edmonds \& Zidek 2010), and has already been reported in introduced pastures and banana plantations (Gámez \& Acconcia 2009, Gámez 2010).

Here we reinforce the unique botanical and faunal characteristics that Amazonian savannahs exhibit, which are considered an important area of endemism within South America (Barbosa et al. 2007). Hence, the studies concerning the fauna of this region should aim to establish conservation strategies associated with this important environment. Our study was the first to document the dung beetle fauna from Roraima savannahs and we believe that knowing the biodiversity is the first step in developing conservation strategies. Thus, since human disturbances threaten these environments (Barbosa et al. 2007, 2011), what leads to biodiversity loss, we reinforce that efforts should be undertaken towards the conservation of intra-Amazonian savannahs. Furthermore, we suggest further studies aiming to understand the effects of human disturbances on the dung beetle diversity in the Brazilian intraAmazonian savannahs.

\section{Acknowledgments}

We thank Lívia Audino, Ross Thomas, the editor and anonymous reviewers for constructive comments on earlier versions of the manuscript. We thank to Fausto França and Edna Macedo for logistical and financial support, also to Daniel Macedo for his invaluable field assistance. We also thank T. Pacheco, L. Vieira and T. Vidaurre for allowing us to use dung beetle photographs from their previous publications; and Amanda Arcanjo and Laís Maia for taking the dung beetle photographs we included in this work. Insect Ecology and Conservation Lab (UFLA) was funded by and CNPq-PELD site 23, and by FAPEMIG, CNPq and CAPES grants. F.F. was awarded a studentship by CAPES (BEX 5528/13-5). F.V.M. was granted by CNPq (405697/2013-9, 302997/2013-0, 484035/2013-4, 202327/ 2013-2) and thanks very especially to the Assis and Estevam families (especially Joana and Pedro Raimundo - in memoriam and Pedro Heber), and Adrian Forsyth for logistical support.

\section{References}

ABOT, A.R., PUKER, A., TAIRA, T.L., RODRIGUES, S.R., KORASAKI, V. \& OLIVEIRA, H.N. 2012. Abundance and diversity of coprophagous beetles (Coleoptera: Scarabaeidae) caught with a light trap in a pasture area of the Brazilian Cerrado. Stud. Neotrop. Fauna Environ. 47:53-60, http://dx.doi.org/10.1080/01650521.2012.662846.

ALMEIDA, S., LOUZADA, J., SPERBER, C. \& BARLOW, J. 2011. Subtle Land-Use Change and Tropical Biodiversity: Dung Beetle Communities in Cerrado Grasslands and Exotic Pastures. Biotropica 43:704-710, http://dx.doi.org/10.1111/j.1744-7429.2011.00751.x.

ANDRADE, R.B., BARLOW, J., LOUZADA, J., VAZ-DE-MELLO, F.Z., SOUZA, M., SILVEIRA, J.M. \& COCHRANE, M.A. 2011. Quantifying Responses of Dung Beetles to Fire Disturbance in Tropical Forests: The Importance of Trapping Method and Seasonality. PLoS One 6:e26208, http://dx.doi.org/10.1371/journal. pone. 0026208 .

AUDINO, L.D., SILVA, P.G., NOGUEIRA, J.M., MORAES, L.P. \& VAZ-DE-MELLO, F.Z. 2011. Scarabaeinae (Coleoptera, Scarabaeidae) de um bosque de eucalipto introduzido em uma região originalmente campestre. Iheringia. Série Zool. 101:121-126.

BARBOSA, R.I. \& CAMPOS, C. 2011. Detection and geographical distribution of clearing areas in the savannas ('lavrado') of Roraima using Google Earth web tool. J. Geogr. Reg. Plann. 4(3):122-136.

BARBOSA, R.I., CAMPOS, C., PINTO, F. \& FEARNSIDE, P. 2007. The "Lavrados" of Roraima: Biodiversity and conservation of Brazil's Amazonian savannas. Funct. Ecosyst. Communities. 1(1):29-41.

BARBOSA, R.I. \& FEARNSIDE, P.M. 2005. Fire frequency and area burned in the Roraima savannas of Brazilian Amazonia. For. Ecol. Manage. 204:371-384, http://dx.doi.org/10.1016/j.foreco.2004.09.011.

BICKNELL, J.E., PHELPS, S.P., DAVIES, R.G., MANN, D.J., STRUEBIG, M.J. \& DAVIES, Z.G. 2014. Dung beetles as indicators for rapid impacts assessments: Evaluating best practice forestry in the neotropics. Ecol. Indic. 43:154-161, http://dx.doi.org/10.1016/j.ecolind. 2014.02.030.

BOILLY, O. \& VAZ-DE-MELLO, F.Z. 2014. Les Scarabaeinae de Guyane: clé illustrée des genres. ACOREP-France Coléoptères Guyane. Tome VII 103-112.

BOITO, G.T., GIUGGIA, J.A., ORNAGHI, J.A., GERARDO, U.A. \& GIOVANINI, D. 2009. Uso de trampas "Barber" para determinar la diversidad de coleópteros epígeos asociados al cultivo de maní (Arachis hypogaea L.). FCA UNCuyo XLI N¹:23-31.

BRÜHL, C. \& KRELL, F.T. 2003. Finding a rare resource: Bornean Scarabaeoidea (Coleoptera) attracted by defensive secretions of 
diplopoda. Coleopt. Bull. 57:51-55, http://dx.doi.org/10.1649/0010065X(2003)057[0051:FARRBS]2.0.CO;2.

CANTIL, L.F., SÁNCHEZ, M.V. \& GENISE, J.F. 2014. The Nest and Brood Ball of Canthon (Canthon) virens aff. paraguayanus Balthasar (Coleoptera: Scarabaeidae: Scarabaeinae). Coleopt. Bull. 68:384-386, http://dx.doi.org/10.1649/072.068.0306.

CARPIO, C., DONOSO, D.A., RAMÓN, G. \& DANGLES, O. 2009. Short term response of dung beetle communities to disturbance by road construction in the Ecuadorian Amazon. Ann. la Société Entomol. Fr. 45:455-469, http://dx.doi.org/10.1080/00379271.2009.10697629.

CAVAlCANTE, C.O., FLORES, A.S. \& BARBOSA, R.I. 2014. Fatores edáficos determinando a ocorrência de leguminosas herbáceas em savanas amazônicas. Acta Amaz. 44(3):379-386, http://dx. doi.org/10.1590/1809-4392201300954.

COPOBIANCO, J.P., VERÍSSIMO, A., MOREIRA, A., SAWER, D., IKEDA, S. \& PINTO, L.P. 2001. Biodiversidade na Amazônia Brasileira: Avaliação de Ações Prioritárias para a Conservação, Uso Sustentável e Repartição de Benefícios. Estação Liberdade, São Paulo.

COSTA, C.M.Q., BARRETTO, J.W. \& DE MOURA, R.D.C. 2014. Changes in the dung beetle community in response to restinga forest degradation. J. Insect Conserv. 18:895-902, http://dx.doi.org/10.1007/ s10841-014-9697-6.

COSTA, C.M.Q., SILVA, F.A.B., FARIAS, Â.I. \& MOURA, R.D.C. 2009. Diversidade de Scarabaeinae (Coleoptera, Scarabaeidae) coletados com armadilha de interceptação de vôo no Refúgio Ecológico Charles Darwin, Igarassu-PE, Brasil. Rev. Bras. Entomol. 53:88-94, http://dx.doi.org/10.1590/S0085-56262009000100021.

COSTA, F.C., PESSOA, K.K.T., LIBERAL, C.N., FILGUEIRAS, B.K.C., SALOMAO, R.P. \& IANNUZZI, L. 2013. What is the importance of open habitat in a predominantly closed forest area to the dung beetle (Coleoptera, Scarabaeinae) assemblage? Rev. Bras. Entomol. 57:329-334, http://dx.doi.org/10.1590/S0085-56262013000300012.

DAMBORSKY, M.P., ALVAREZ BOHLE, M.C., IBARRA POLESEL, M.G., PORCEL, E.A. \& FONTANA, J.L. 2015. Spatial and Temporal Variation of Dung Beetle Assemblages in a Fragmented Landscape at Eastern Humid Chaco. Neotrop. Entomol. 44:30-39, http://dx.doi.org/ 10.1007/s13744-014-0257-2.

DURÃES, R., MARTINS, W.P. \& VAZ-DE-MELLOS, F.Z. 2005. Dung beetle (Coleoptera: Scarabaeidae) assemblages across a natural forest-cerrado ecotone in Minas Gerais, Brazil. Neotrop. Entomol. 34:721-731, http://dx.doi.org/10.1590/S1519-566X2005000500003.

EDMONDS, W.D. \& ZIDEK, J. 2010. Taxonomic review of the Neotropical genus Coprophanaeus Olsoufieff, 1924 (Coleoptera: Scarabaeidae, Scarabaeinae). Insecta mundi Paper 649, 49-63.

ENDRES, A.A., CREÃO-DUARTE, A.J. \& HERNÁNDEZ, M.I.M. 2007. Diversidade de Scarabaeidae s. str. (Coleoptera) da Reserva Biológica Guaribas, Mamanguape, Paraíba, Brasil: uma comparação entre Mata Atlântica e Tabuleiro Nordestino. Rev. Bras. Entomol. 51:67-71, http://dx.doi.org/10.1590/S0085-56262007000100012.

ESCOBAR, F. 1997. Estudio de la comunidad de coleópteros coprófagos (Scarabeidae) en un remanente de Bosque Seco al Norte del Tolima, Colombia. Caldasia 19:419-430.

ESCOBAR, F., LOBO, J.M. \& HALFFTER, G. 2005. Altitudinal variation of dung beetle (Scarabaeidae: Scarabaeinae) assemblages in the Colombian Andes. Glob. Ecol. Biogeogr. 14:327-337, http://dx.doi.org/ 10.1111/j.1466-822X.2005.00161.x.

FABRICIUS, J.C. 1804. Systema Piezatorum secundum ordines, genera, species, adjectis, synonymis, locis, observationnibus, descriptionibus. (Reichard, C). Brunswick XIV, pp. 15-439.

FALQUETO, S.A., VAZ-DE-MELLO, F.Z. \& SCHOEREDER, J.H. 2005. Are fungivorous Scarabaeidae less specialist? Ecol. Austral 15:17-22, http://dx.doi.org/S1667-782X2005000100003.

FERREIRA, L.V. 2001. Identificação de áreas prioritárias para a conservação da biodiversidade por meio da representatividade das unidades de conservação e tipos de vegetação nas ecorregiões da Amazônia brasileira, In: Biodiversidade na Amazônia Brasileira (Veríssimo, A. Moreira, A. Sawer, D. Santos, I. Pinto, L.P. \&
Copobianco, J.P. eds.). Editora Liberdade, Instituto Socioambiental, São Paulo, pp. 268-286.

FERRER-PARIS, J.R., SÁNCHEZ-MERCADO, A. \& RODRÍGUEZ, J.P. 2013. Optimización del muestreo de invertebrados tropicales: Un ejemplo con escarabajos coprófagos (Coleoptera: Scarabaeinae) en Venezuela. Rev. Biol. Trop. 61:89-110, http://dx.doi.org/10.15517/ rbt.v61i1.10941.

FILGUEIRAS, B.K.C., TABARELLI, M., LEAL, I.R., VAZ-DEMELLO, F.Z. \& IANNUZZI, L. 2015. Dung beetle persistence in human-modified landscapes: Combining indicator species with anthropogenic land use and fragmentation-related effects. Ecol. Indic. 55:65-73, http://dx.doi.org/10.1016/j.ecolind.2015.02.032.

FLECHTMANN, C.A.H., TABET, V.G. \& QUINTERO, I. 2009. Influence of carrion smell and rebating time on the efficiency of pitfall traps to dung beetle sampling. Entomol. Exp. Appl. 132:211-217, http://dx.doi.org/10.1111/j.1570-7458.2009.00885.x.

FORTI, L.C., RINALDI, I.M.P., CAMARGO, R., DA S. \& FUJIHARA, R.T. 2012. Predatory Behavior of Canthon virens (Coleoptera: Scarabaeidae): A Predator of Leafcutter Ants. Psyche. 2012:1-5, http://dx.doi.org/10.1155/2012/921465.

GÁMEZ, J. 2010. Escarabajos necrófagos (Coleoptera: Scarabaidae: Scarabainae: Phanaeini y Coleoptera: Silphidae: Nicrophorinae y Silphinae) de la Cordillera de los Andes, depresión de Maracaibo y Llanos de Venezuela. Kempffiana 6:15-19.

GÁMEZ, J. \& ACCONCIA, R. 2009. Ecological informations on Coprophanaeus (Coprophanaeus) gamezi Arnaud (Coleoptera: Scarabaeidae: Phanaeini) in a rural agricultural area in the depression of Maracaibo. Zulia State. Venezuela. Acta Zool. Mex. Nueva Ser. 25:387-396.

GÉNIER, F. 1996. A revision of the Neotropical genus Ontherus Erichson (Coleoptera: Scarabaeidae, Scarabaeinae). Mem. Entomol. Soc. Canada 128:1-170, http://dx.doi.org/10.4039/entm128170fv.

GILL, B.D. 1991. Dung beetles in tropical American forests. In: Dung Beetle Ecology (Cambefort, I \& Hanski, Y. eds.), Princeton University Press, Princeton, pp. 211-229.

GRIES, R., LOUZADA, J., ALMEIDA, S., MACEDO, R. \& BARLOW, J. 2012. Evaluating the impacts and conservation value of exotic and native tree afforestation in Cerrado grasslands using dung beetles. Insect Conserv. Divers. 5:175-185, http://dx.doi.org/10.1111/ j.1752-4598.2011.00145.x.

HALFFTER, G. \& HALFFTER, V. 2009. Why and where coprophagous beetles (Coleoptera: Scarabaeinae) eat sedes, fruits or vegetable detritus. Bol. Soc. Entomol. Aragonesa. 45:1-22.

HALFFTER, G. \& MARTÍNEZ, A. 1966. Revisión monográfica de los Canthonina americanos (Coleoptera, Scarabaeidae). Rev. Soc. Mex. Hist. Nat. 27:89-117.

HALFFTER, G. \& MARTÍNEZ, A. 1977: Revision monografi ca de los Canthonina Americanos, IV parte. Clava parageneros y subgeneros. Folia Entomológica Mex. 38:29-107

HALFFTER, G. \& MATTHEWS, E.G. 1966. The natural history of dung beetles of the subfamily Scarabaeinae (Coleoptera: Scarabaeidae). Folia Entomológica Mex. 12:1-312.

HERNANDÉZ, M.I.M. 2007. Besouros Escarabeíneos (Coleoptera: Scarabaeidae) da Caatinga Paraibana, Brasil. Oecologia Bras. 11:356-364, http://dx.doi.org/10.4257/oeco.2007.1103.06.

HERTEL, F. \& COLLI, G.R. 1998. The use of leaf-cutter Ants, Atta laevigata (Smith) (Hymenoptera: Formicidae), as a substrate for oviposition by the dung beetle Canthon virens Mannerheim (Coleoptera: Scarabaeidae) in central Brazil. Coleopt. Bull. 52:105-108.

HUBBER, O. 2006. Herbaceous ecosystems on the Guyana Shield, a regional overview. J. Biogeogr. 33:464 475, http://dx.doi.org/10.1111/ j.1365-2699.2005.01454.x.

JUNK, W.J. 1983. As águas da região Amazônica. In: Amazônia: Desenvolvimento, Integração E Ecologia (Salati, E. Junk, W.J. Shubart, H.O.R. \& Oliveira, A. eds.). Editora Brasiliense, São Paulo, pp. 45-100.

KORASAKI, V., VAZ-DE-MELLO, F.Z., BRAGA, R.F., ZANETTI, R. \& LOUZADA, J. 2012. Taxocenose de Scarabaeinae (Coleoptera: 
Scarabaeidae) em Benjamin Constant, AM. Acta Amaz. 42:423-432, http://dx.doi.org/10.1590/S0044-59672012000300015.

KRIŠTOFÍK, J., MAŠ́ÁN, P., ŠUSTEK, Z. \& KLOUBEC, B. 2003. Arthropods (Pseudoscorpionida, Acari, Coleoptera, Siphonaptera) in nests of the tengmalm's owl, Aegolius funereus. Biol. Bratislava. 58:231-240.

LARSEN, T.H. 2011. Dung beetles of the Kwamalasamutu region, Suriname (Coleoptera: Scarabaeidae: Scarabaeinae). In: . eds.). A Rapid Biological Assessment of the Kwamalasamutu Region, Southwestern Suriname. RAP Bulletin of Biological Assessment 63. Conservation International, Arlington, pp. 91-103.

LIMA, M.G.A., SILVA, R.P., DE, A., SOUSA, M.D.F. \& COSTA, E.M. 2013. Diversidade de Scarabaeinae (Coleoptera: Scarabaeidae) no Parque Botânico do Ceará, Caucaia - CE, Brasil. Rev. Ago@mbiente On-line 7:89-94, http://dx.doi.org/10.18227/1982-8470ragro.v7i1.970.

LOPES, P.P., LOUZADA, J.N.C. \& VAZ-DE-MELLO, F.Z. 2006. Organization of dung beetle communities (Coleoptera: Scarabaeidae) in areas of vegetation re-establishment in Feira de Santana, Bahia, Brazil. Sitientibus Série Ciências Biológicas 6:261-266.

LOUZADA, J., GARDNER, T., PERES, C. \& BARLOW, J. 2010. A multi-taxa assessment of nestedness patterns across a multiple-use Amazonian forest landscape. Biol. Conserv. 143:1102-1109, http:// dx.doi.org/10.1016/j.biocon.2010.02.003.

LOUZADA, J.N.C., LOPES, F.S. \& VAZ-DE-MELLO, F.Z. 2007. Structure and composition of a dung beetle community (Coleoptera: Scarabaeinae) in a small forest patch from Brazilian Pantanal. Zoociências 9:199-203.

LOUZADA, J.N.C. \& SILVA, P.R.C.E. 2009. Utilisation of introduced Brazilian pastures ecosystems by native dung beetles: Diversity patterns and resource use. Insect Conserv. Diver. 2:45-52, http:// dx.doi.org/10.1111/j.1752-4598.2008.00038.x.

LOZANO, C. 2010. Nuevos registros de escarabajos coprófagos para la Orchila, Sierra de Perijá, Venezuela. Boletín Cent. Investig. Biológicas 44:83-89.

LUEDERWALDT, H. 1929. As espécies brasileiras do gênero Pinotus. (Coleoptera - Lamellicornidae - Coprini), com algumas considerações também sobre outras espécies. Rev. do Mus. Paul. 16, 603-775.

MATAVELLI, R.A. \& LOUZADA, J.N.C. 2008. Invasão de áreas de savana intra-amazônicas por Digitonthophagus gazella (Fabricius, 1787) (Insecta: Coleoptera: Scarabaeidae). Acta Amaz. 38:153-158, http://dx.doi.org/10.1590/S0044-59672008000100017.

MEDINA, A.M. \& LOPES, P.P. 2014. Resource utilization and temporal segregation of Scarabaeinae (Coleoptera: Scarabaeidae) community in a caatinga fragment. Neotrop. Entomol. 43:127-133, http://dx.doi.org/10.1007/s13744-014-0198-9.

MEDRI, Í.M. \& LOPES, J. 2001. Scarabaeidae (Coleoptera) do Parque Estadual Mata dos Godoy e de área de pastagem, no norte do Paraná, Brasil. Rev. Bras. Zool. 18:135-141, http://dx.doi.org/10.1590/S010181752001000500011.

MENESES, M.E.N.S., COSTA, M.L. \& COSTA, J.A.V. 2007. Os lagos do lavrado de Boa Vista - Roraima?: fisiografia , físico-química das águas, mineralogia e química dos sedimentos. Rev. Bras. Geociências 37:478-489.

MILHOMEM, M.S., MELLO, F.Z.V. \& DINIZ, I.R. 2003. Técnicas de coleta de besouros copronecrófagos no Cerrado. Pesqui. Agropecuária Bras. 38:1249-1256, http://dx.doi.org/10.1590/S0100-204X 2003001100001.

NICHOLS, E., SPECTOR, S., LOUZADA, J., LARSEN, T., AMEZQUITA, S. \& FAVILA, M.E. 2008. Ecological functions and ecosystem services provided by Scarabaeinae dung beetles. Biol. Conserv. 141:1461-1474, http://dx.doi.org/10.1016/j.biocon.2008.04.011.

NORIEGA, J.A., SOLIS, C., ESCOBAR, F. \& REALPE, E. 2007. Escarabajos coprófagos (Coleoptera: Scarabaeidae) de la provincia de la Sierra Nevada de Santa Marta. Biota Colomb. 8:77-86.

NOVELO, E.R., DELFÍN-GONZÁLEZ, H. \& MORÓN, M.Á. 2007. Copro-necrophagous beetle (Coleoptera: Scarabaeidae) diversity in an agroecosystem in Yucatan, Mexico. Rev. Biol. Trop. 55:83-99, http://dx.doi.org/10.15517/rbt.v55i1.6059.
NUNES, R.V., FRIZZAS, M.R. \& VAZ-DE-MELLO, F.Z. 2012. Scarabaeinae (Coleoptera: Scarabaeidae) of a rupestrian field at Caatinga, Distrito Federal, Brazil: commented list of species. Biota Neotrop. 12(4):125-129, http://dx.doi.org/10.1590/S1676-06032012 000400013

PACHECO, T.L. \& VAZ-DE-MELLO, F.Z. 2015. Dung beetles of the tribe Phanaeini (Coleoptera: Scarabaeidade: Scarabaeinae) from Roraima state, Northern Brazil: checklist and key to species. Biota Neotrop. 15(2): 1-9, http://dx.doi.org/10.1590/1676-06032015014514.

PADILLA-GIL, D.N. \& HALFFTER, G. 2007. Biogeography of the areas and Canthonini (Coleoptera: Scarabaeidae) of dry tropical forests in mesoamerica and colombia. Acta Zoológica Mex. 23:73-108.

PRANCE, G.T. 1996. Islands in Amazonia. Philos. Trans. R. Soc. B Biol. Sci. 351, 823-833, http://dx.doi.org/10.1098/rstb.1996.0077.

PUKER, A., CORREA, C.M.A., KORASAKI, V., FERREIRA, K.R. \& OLIVEIRA, N.G. 2013. Dung Beetles (Coleoptera: Scarabaeidae) Attracted to Dung of the Largest Herbivorous Rodent on Earth: A Comparison with Human Feces. Environ. Entomol. 42:1218-1225, http://dx.doi.org/10.1603/EN13100.

RIBEIRO, J.E.L.S., HOPKINS, M.J.G., VICENTINI, A., SOTHERS, C.A., COSTA, M.A.S., BRITO, J.M., SOUZA, M.A.D., MARTINS, L.H.P., LOHMANN, L.G., ASSUNÇÃO, P.A.C.L., PEREIRA, E.C., SILVA, C.F., MESQUITA, M.R., \& PROCOPIO, L.C. 1999. Flora da reserva Ducke: guia de identificação das plantas vasculares de uma floresta de terra-firme na Amazônia Central. DFID - INPA, Manaus.

RODRIGUES, S.R., BARROS, A.T.M., PUKER, A. \& TAIRA, T.L. 2010. Diversidade de besouros coprófagos (Coleoptera, Scarabaeidae) coletados com armadilha de interceptação de voo no Pantanal Sul-Mato-Grossense, Brasil. Biota Neotrop. 10(2):123-127, http://dx.doi.org/10.1590/S1676-06032010000200015.

ROSA, T.A., BABATA, M.L.Y., SOUZA, C.M., SOUSA, D., MELLOPATIU, C.A., VAZ-DE-MELLO, F.Z. \& MENDES, J. 2011. Arthropods associated with pig carrion in two vegetation profiles of Cerrado in the State of Minas Gerais, Brazil. Rev. Bras. Entomol. 55:424 434, http://dx.doi.org/10.1590/S0085-56262011005000045.

SALOMÃO, R.P. \& IANNUZZI, L. 2015. Dung beetle (Coleoptera, Scarabaeidae) assemblage of a highly fragmented landscape of Atlantic forest: from small to the largest fragments of northeastern Brazilian region. Rev. Bras. Entomol. 59:126-131, http://dx.doi.org/ 10.1016/j.rbe.2015.03.008.

SANAIOTTI, T.M. 1997. Comparação fitossociológica de quatro savanas de Roraima. In: Homem, Ambiente e Ecologia no Estado de Roraima (Barbosa, R.I Ferreira, E.J.G \& Castellón, E. eds.). INPA, Manaus, pp. 481-488.

SANAIOTTI, T.M., MARTINELLI, L.A., VICTORIA, R.L., TRUMBORE, S.E. \& CAMARGO, P.B. 2002. Past vegetation changes in Amazon savannahs determined using carbon isotopes of soil organic matter. Biotropica 34:2-16, http://dx.doi.org/10.1111/j.17447429.2002.tb00237.x.

SÁNCHEZ-HUERTA, J.L., TONELLI, M., ZUNINO, M. \& HALFFTER, G. 2015. Redescription of Onthophagus halffteri Zunino (Coleoptera: Scarabaeidae: Scarabaeinae), with Ecological and Distributional Notes. Coleopt. Bull. 69:225-230, http://dx.doi.org/10.1649/ 0010-065X-69.2.225.

SANTOS, W., ALVES, A. \& CREÃO-DUARTE, A. 2014. Beetles (Insecta, Coleoptera) associated with pig carcasses exposed in a Caatinga area, Northeastern Brazil. Brazilian J. Biol. 74:649-655, http://dx.doi.org/10.1590/bjb.2014.0072.

SARMIENTO, G. 1984. The Ecology of Neotropical Savannahs. Harvard University Press, Cambridge, UK.

SCHEFFLER, P.Y. 2005. Dung beetle (Coleoptera: Scarabaeidae) diversity and community structure across three disturbance regimes in eastern Amazonia. J. Trop. Ecol. 21:9-19, http://dx.doi.org/ 10.1017/S0266467404001683.

SCHIFFLER, G., VAZ-DE-MELLO, F.Z. \& AZEVEDO, C.O. 2003. Scarabaeidae s. str. (Coleoptera) from the Doce river and Suruaca valleu in Linhares municipality, Espírito Santo State, Brazil. Rev. Bras. Zoociências 5:205-211. 
SCHMITT, T., KRELL, F.T. \& LINSENMAIR, K.E. 2004. Quinone mixture as attractant for necrophagous dung beetles specialized on dead millipedes. J. Chem. Ecol. 30:731-740, http://dx.doi.org/ 10.1023/B:JOEC.0000028428.53797.cb.

SILVA, P.G., VAZ-DE-MELLO, F.Z. \& MARE, R.A. 2011. Guia de identificação das espécies de Scarabaeinae (Coleoptera: Scarabaeidae) do município de Santa Maria, Rio Grande do Sul, Brasil. Biota Neotrop. 11(4):329-345, http://dx.doi.org/10.1590/S167606032011000400027.

SILVA, F.A.B., COSTA, C.M.Q., MOURA, R.C. \& FARIAS, A.I 2010. Study of the dung beetle (Coleoptera: Scarabaeidae) community at two sites: Atlantic forest and clear-cut, Pernambuco, Brazil. Environ. Entomol. 39:359-367, http://dx.doi.org/10.1603/EN09180.

SILVA, F.A.B., HERNÁNDEZ, M.I.M., IDE, S. \& MOURA, R.C. 2007. Comunidade de escarabeíneos (Coleoptera, Scarabaeidae) copronecrófagos da região de Brejo Novo, Caruaru, Pernambuco, Brasil. Rev. Bras. Entomol. 51:228-233, http://dx.doi.org/10.1590/ S0085-56262007000200014.

SILVA, P. \& AUDINO, L.D. 2011. Escarabeíneos (Coleoptera: Scarabaeidae) atraídos a diferentes iscas em campo nativo de Bagé, Rio Grande do Sul, Brasil. Rev. Bras. Zoociências 13:241-247.

SILVA, P.G., ROSA-GARCIA, A.M. \& VIDAL, M.B. 2008. Espécies de besouros copro-necrófagos (Coleoptera: Scarabaeidae) da Região da Campanha do Rio Grande do Sul. Rev. Ciências Agroveterinárias 7:143-149.

SILVA, R.J., COLETTI, F., COSTA, D. \& VAZ-DE-MELLO, F.Z. 2014. Rola-bostas (Coleoptera: Scarabaeidae: Scarabaeinae) de florestas e pastagens no sudoeste da Amazônia brasileira: Levantamento de espécies e guildas alimentares. Acta Amaz. 44:345-352, http://dx.doi.org/ 10.1590/1809-4392201304472.

SILVA, R.J., DINIZ, S. \& VAZ-DE-MELLO, F.Z. 2010. Heterogeneidade do habitat, riqueza e estrutura da assembléia de besouros rola-bostas (Scarabaeidae: Scarabaeinae) em áreas de cerrado na Chapada dos Parecis, MT. Neotrop. Entomol. 39:934-940, http://dx.doi.org/10.1590/ S1519-566X2010000600014.

SILVA, R.J., RIBEIRO, H.V., SOUZA, M.F. \& VAZ-DE-MELLO, F.Z. 2015. Influence of soil granulometry on the structure of functional guilds of dung beetles (Coleoptera: Scarabaeidae: Scarabaeinae) at semideciduos forests in the State of Mato Grosso, Brazil. Biosci. J. 31:601-612, http://dx.doi.org/10.14393/BJ-v31n1a2015-23525.

SLAY, M.E., SKELLEY, P.E. \& TAYLOR, S.J. 2012. Howden and Cartwright (Coleoptera: Scarabaeidae) from Ozark Caves, with a Review of Scarabaeoids Reported from North American Caves. Coleopt. Bull. 66:187-199, http://dx.doi.org/10.1649/072.066.0302.

SOLÍS, C., NORIEGA, J.A. \& HERRERA, G. 2011. Escarabajos coprófagos (Coleoptera: Scarabaeinae) en tres bosques secos del departamento del Atlántico-Colombia. Boletín del Mus. Entomol. la Univ. del Val. 12:33-41.

TARASOV, S.I. \& KABAKOV, O.N. 2010. Two new species of Onthophagus (Coleoptera: Scarabaeidae) from Indochina, with a discussion of some problems with the classification of Serrophorus and similar subgenera. Zootaxa 2344:17-28.

VANZOLINI, P.E. \& CARVALHO, C.M. 1991. Two sibling and sympatric species of Gymnophthalmus in Roraima, Brazil (Sauria Teiidae). Pap. Avulsos Zool. 37:173-226.

VAZ-DE-MELLO, F.Z. \& LOUZADA, J.N.C. 1997. Considerações sobre o forrageio arbóreo por Scarabaeidae (Coleoptera, Scarabaeoidea) e dados sobre sua ocorrência em floresta tropical do Brasil. Acta Zool. Mex. Nueva Ser. 72:55-61.

VAZ-DE-MELLO, F.Z., LOUZADA, J.N.C. \& SCHOEREDER, J.H. 1998. New data and comments on Scarabaeidae (Coleoptera: Scarabaeoidea) associated with Atini (Hymenoptera: Formicidae). Coleopt. Bull. 52:209-216.

VAZ-DE-MELLO, F.Z. 1999a. Scarabaeidae do Estado de Roraima. Memórias da IV Reunião Latino-Americana de Scarabaeoidologia, Viçosa, MG, p. 78-79.

VAZ-DE-MELLO, F.Z. 1999b. Scarabaeidae s. str. (Coleoptera: Scarabaeoidea) de um fragmento de Floresta Amazônica no estado do Acre, Brasil. 1. Taxocenose. An. da Soc. Entomológica do Bras. 28:439-446, http://dx.doi.org/10.1590/S0301-80591999000300009.

VAZ-DE-MELLO, F.Z. 2000. Estado Atual de conhecimentos dos Scarabaeidae s. str. (Coleoptera: Scarabaeoidea) do Brasil. In: Hacia Un Proyecto CYTED Para El Inventario Y Estimación de La Diversidad Entonológica Em Iberoamérica: PrIBES-2000 (Martín-Piera, F. Morrone, J.J. \& Melic, A. eds.). Sociedad Entomologica Aragonesa \& CYTED, Zaragoza, pp. 181-195.

VIDAURRE, T., GONZALES, L. \& LEDEZA, J.M. 2008. Escarabajos coprófagos (Scarabaeidae: Scarabaeinae) del Palmar de las Islas, Santa Cruz, Bolívia. Kempffiana 4:3-20.

VIEGAS, G., STENERT, C., SCHULZ, U.H. \& MALTCHIK, L. 2014. Dung beetle communities as biological indicators of riparian forest widths in southern Brazil. Ecol. Indic. 36:703-710, http://dx.doi.org/ 10.1016/j.ecolind.2013.09.036.

VIEIRA, L., LOUZADA, J.N.C. \& SPECTOR, S. 2008. Effects of degradation and replacement of Southern Brazilian Coastal Sandy Vegetation on the dung beetles (Coleoptera: Scarabaeidae). Biotropica 40:719-727, http://dx.doi.org/10.1111/j.1744-7429.2008.00432.x.

VIEIRA, L. \& SILVA, F.A.B. 2012. List Dung beetles (Coleoptera: Scarabaeidae: Scarabaeinae) of the Floresta Nacional Contendas do Sincorá, Bahia, Brazil. Check List 8:733-739.

VILLALOBOS, F.J., DIAZ, A. \& FAVILA, M.E. 1998. Two species of Canthon feed on dead and live invertebrates. Coleopt. Bull. 52:101-104. 